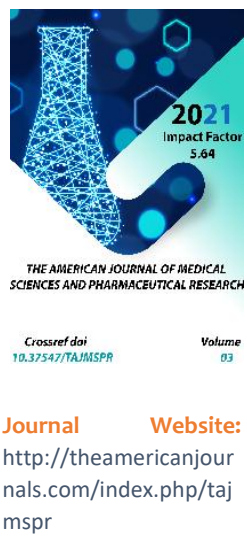

Copyright: Original content from this work may be used under the terms of the creative commons attributes

\section{Formation Of Young People Of The Younger Generation In Uzbekistan As A Science-Driven Process}

\author{
Yu.M.Khalimbetov \\ Associate Professor, Samarkand State Medical Institute, Samarkand, Uzbekistan \\ Yuldashev S.J \\ Associate Professor, Samarkand State Medical Institute, Samarkand, Uzbekistan \\ Murodova U.R \\ Assistant, Samarkand State Medical Institute, Samarkand, Uzbekistan
}

\title{
ABSTRACT
}

One of the key priorities of the reforms in the years of independence was the creation of a fundamentally new, modern education system. At the initiative and under the direct leadership of the First President Islam Karimov, documents of great importance were developed -the " Law on Education "and the" National Program for Training Personnel.

\section{KEYWORDS}

Law on Education, manager, democratic, system.

\section{INTRODUCTION}

In accordance with them, a steady movement forward on the path of transformation and modernization began. Success in solving this problem creates a reliable basis for further improvement of the scientific organization of the formation of a new personality in accordance with the requirements of President Sh.M. Mirziyoyev "Critical analysis,strict discipline and personal responsibility" should become the daily norm in the activities of every manager. The formation of a fully and harmoniously developed personality is considered in the President's speeches in several main aspects: first, as an objective need for today's progress, second, as the highest goal of creating a new independent state, and third, as a condition for the formation of an Independent democratic state in the socioeconomic formation.As we move forward ,Sh. M. Mirziyoyev pointed out, the society will move to the education, training and training of comprehensively developed and comprehensively trained young people. This 
formulation of the question reflects not only the humanistic nature of the country's leadership, but also its scientific nature, since the goals of theory and practice for the development of society, which are subjective factors of social development,coincide with the objective needs of social progress. The role of young people is not just increasing ,it is changing qualitatively, because the intensification and modernization of the country is developing as a result of the conscious and purposeful activity of young people.The social activity of young people is filled with new content, it organically combines productive work with management work.The implementation of the action strategy for 2017-2021 is impossible without a radical modernization of the economy, social, spiritual and moral spheres, the style of work of economic bodies,public organizations.An important priority for the state is the identification and comprehensive development of talent. Big changes in their essence and content, goals and objectives, scope and method are a real evolution, a turning point in the entire system of social relations, in the minds and hearts of young people, their psychology and understanding of the current stage of development of Uzbekistan.It is irreversible, must be carried out simultaneously from above and from below, cover all levels of government, all links of political and state leadership, will close with changes in the labor collectives.The real conditions of Uzbekistan are a living social organism, which, for various reasons, is not free from shortcomings in its development.But we must not forget the main thing: the success of the young generation in Uzbekistan, their social activity in the management of its production and all other areas are indisputable historical achievements.At the same time, it is necessary to honestly and fundamentally reveal the existing shortcomings, unresolved problems, mistakes, miscalculations and omissions in the course of building an independent state,analyze the causes of their occurrence,develop methods and forms of overcoming them. At the same time, the elements of selforganization and self-management of the primary level of the labor collective are expanding, the creative search for new forms and methods of "bottom-up" influence on production management processes is increasing. The relationship between the members of the brigade does not fit into the traditional "order-submission" scheme.Collective discussion and practical solution of topical issues of the work of the team creates an environment of mutual demands, promotes a sense of responsibility for the results of work. Now the young worker becomes not only the executor of the adopted management decisions,but also necessarily takes a direct part in their development. He performs not only an object of management, but also an active subject of management activity.The level of social activity is largely determined by the content of organizational, ideological, spiritual and moral educational work of trade unions and youth organizations.Therefore, the scientific management of the social activity of the young generation means to form, educate and fully develop the need for every young worker to directly participate in the management of the enterprise and the entire Uzbek production.It is important to keep in mind that the democratic principles in the management of production do not act themselves by myself, and they are implemented through the social activity of young people, are embodied in the activities of state bodies and social organizations.Thus, social activity is a kind of spring for improving national democracy in the sphere of material production and the entire society.Under the social activity of the younger generation in the management of 
material production, it is necessary to understand their consciously purposeful actions aimed at the realization of their democratic rights and freedoms, assuming high responsibility for production,as well as a specific personal contribution to the development, adoption and implementation of management decisions.The research task has matured to thoroughly study the process of social activity of young people in the management of all the diverse relations that arise in the field of national economy.Successful efforts will strengthen the young people's sense of responsibility for the common cause,develop their qualities as the owner of production,the creator and consumer of material goods. Justifying this position, it is necessary to note the new economic managers who consider the human factor only from the position of "labor resources"," carrier of labor force " look at the young worker as the performer of a specific production activity.- labor function. The structure of the concept of "human factor" must necessarily include the care of a person-a worker,an increasingly complete satisfaction of his material and cultural needs.It is only on this humanistic basis that it is possible to achieve such a situation that an employee works in his place conscientiously, showing high consciousness, responsibility for the assigned task,and actively uses his creative abilities .The activation of the human factor is one of the decisive prerequisites for accelerating social development.- economic development of the country.At the same time, this is the goal of acceleration, because in the new conditions, the young person is a worker in the goal of society's development.Without this, it is almost impossible to successfully solve the diverse, large-scale and extremely complex tasks of intensifying the socioeconomic development of the country.The central figure, the main subject of modernization is a young man-a hard
worker.Acceleration is carried out not only in the name of the individual, but by himself by increasing social activity in all spheres of life of our multinational country.

\section{REFERENCES}

1. Davies, S. W. (2001). Clinical presentation and diagnosis of coronary artery disease: stable angina. British medical bulletin, 59(1), $17-27$.

2. Davies, S. W. (2001). Clinical presentation and diagnosis of coronary artery disease: stable angina. British medical bulletin, 59(1), 17-27.

3. Ghuran, A. V., \& Camm, A. J. (2001). Ischaemic heart disease presenting as arrhythmias. British medical bulletin, 59(1), 193-210.

4. Bailey, R. L., Thuppal, S. V., Sherif, K. D., Denby, N., Steinbaum, S. R., Haycock, B., ... \& von Schacky, C. (2019). No Relationship Between Serum $25(\mathrm{OH})$ Vitamin D Concentrations and Perceptions of Vitamin D Dietary Intake Adequacy in US and German Adults Not Using Dietary Supplements. In Nutritional Influences on Bone Health (pp. 247-256). Springer, Cham.

5. Daull, P., Jeng, A. Y., \& Battistini, B. (2007). Towards triple vasopeptidase inhibitors for the treatment of cardiovascular diseases. Journal of cardiovascular pharmacology, 50(3), 247-256.

6. Sobirovna, T. R. (2021). Issues of further improvement of water cadastre legislation of Uzbekistan. ACADEMICIA: An International Multidisciplinary Research Journal, 11(4), 1241-1253.

7. Blanco-Colio, L. M. (2014). TWEAK/Fn14 axis: a promising target for the treatment of cardiovascular diseases. Frontiers in immunology, 5, 3 . 
8. DiNicolantonio, J. J., Liu, J., \& O’Keefe, J. H. (2018). Magnesium for the prevention and treatment of cardiovascular disease.

9. Bale, J. R., Ryan, T. J., Reddy, K. S., \& Howson, C. P. (Eds.). (1998). Control of cardiovascular diseases in developing countries: research, development, and institutional strengthening. National Academies Press.

10. Beaglehole, R., Saracci, R., \& Panico, S. (2001). Cardiovascular diseases: causes, surveillance and prevention. International Journal of Epidemiology, 30(suppl_1), S1.

11. Prabhakaran, D., Jeemon, P., \& Roy, A. (2016). Cardiovascular diseases in India: current epidemiology and future directions. Circulation, 133(16), 1605-1620. 